\title{
Alkali carbonates and chlorine in kimberlites from Canada and Greenland: evidence from melt inclusions and serpentine
}

\author{
Vadim S. Kamenetsky ${ }^{1}$, Maya B. Kamenetsky ${ }^{1}$, Yakov Weiss ${ }^{2}$, Oded Navon ${ }^{2}$, Troels F. D. \\ Nielsen $^{3}$ and Terry P. Mernagh ${ }^{4}$ \\ ${ }^{1}$ CODES and School of Earth Sciences, University of Tasmania, Hobart, TAS, Australia \\ ${ }^{2}$ Institute of Earth Sciences, the Hebrew University of Jerusalem, Israel \\ ${ }^{3}$ Geological Survey of Denmark and Greenland, Copenhagen, Denmark \\ ${ }^{4}$ Geoscience Australia, Canberra, Australia
}

\section{Introduction}

The source and origin of alkali carbonates and chlorides in the groundmass of the Udachnaya-East kimberlites is still controversial, given the fact that other group-I kimberlites are devoid of these minerals, but have serpentine (Kamenetsky et al., 2004; Kamenetsky et al., 2007). A choice between crustal and mantle origin of the Udachnaya-East unique compositional features is utterly important in deciding whether the Udachnaya-East kimberlite is a "black sheep" in the kimberlite clan or a bearer of the true identity of the primary kimberlite melt, and by inference, can provide constraints on the composition of the mantle source and mantle melting process. If the enrichment of the Udachnaya-East kimberlite in alkali carbonates and chlorides reflects a primary mantlederived signature, it could have been present in other group-I kimberlites prior to obliteration by common pervasive alteration. Study of melt inclusions trapped in magmatic phenocrysts during crystallisation allows seeing compositions beyond the effects of postmagmatic modifications. Thus, we selected kimberlite samples where partial preservation of olivine phenocrysts made possible compositional and thermometric studies of melt inclusions entrapped in olivine. Another prerequisite to our study was selection of kimberlites emplaced into magmatic or metamorphic rocks in the terranes containing little or no sedimentary cover, namely the Gahcho Kué, Jericho, Aaron and Leslie pipes in the Slave Craton, Canada (Fedortchouk and Canil, 2004; Hetman et al., 2004; Price et al., 2000) and the Majuagaa dyke in southern West Greenland (Nielsen and Jensen, 2005).

\section{Samples}

All samples in this study belong to group-I (or type-I) hypabyssal facies kimberlites, and are texturally and compositionally (major and trace elements) similar to each other and to the Udachnaya-East kimberlites. The main difference between the compositions of Canadian and Greenland rocks and Udachnaya-East kimberlites is in the abundances of $\mathrm{Na}_{2} \mathrm{O}$ and $\mathrm{H}_{2} \mathrm{O}$. The former are invariably depleted in $\mathrm{Na}_{2} \mathrm{O}$ (0.06-0.26 wt\%), but enriched in $\mathrm{H}_{2} \mathrm{O}$ (2.3-8.0 wt\%) compared to the Udachnaya-East kimberlites, where $\mathrm{Na}_{2} \mathrm{O}$ (0.15-6.2 $w t \%)$ and $\mathrm{H}_{2} \mathrm{O}$ (4.5-0.16wt\%) are negatively correlated. Abundant olivine phenocrysts in the serpentine-calcite \pm dolomite-phlogopite-(Fe-Ti-Cr)oxides-perovskite \pm monticellite groundmass are entirely or partially preserved. In general, the olivine cores span a significant range in terms of forsterite (Fo) content from 85 to $93 \mathrm{~mol} \%$, whereas the rims of olivine in each sample have almost constant Fo (91.5 \pm 0.5 mol\% in the Leslie and Aaron kimberlite (Fedortchouk and Canil, 2004), and 88.6 $0.2 \mathrm{~mol} \%$ in the Majuagaa kimberlite (Nielsen and Jensen, 2005)). Such compositional features are strikingly similar to those of olivine phenocrysts in the Udachnaya-East kimberlite (Kamenetsky et al., 2008), where olivine cores range in Fo (85-93 mol\%), and the rims have nearly constant Fo (89.0 $\pm 0.2 \mathrm{~mol} \%)$, but variable trace element compositions.

\section{Melt inclusions}

Olivine phenocrysts in all studied kimberlites contain crystal, vapour-rich and melt-rich inclusions, with the latter type prevailing in size and abundance. Multiphase melt inclusions (Fig. 1) are trapped in the olivine rims or along healed fractures through the cores, and thus are secondary in origin with respect to olivine cores and primary and pseudosecondary with respect to olivine rims. They consist of several (up to ten) translucent and opaque daughter phases and deformed vapour bubble(s) filling the spaces between solids (Fig. 1). The compositions of daughter minerals and whole inclusions were studied using laser Raman spectroscopy, energy-dispersive (EDS) and wavelength dispersive (WDS) X-ray spectroscopy, and laser ablation ICPMS.

The following minerals were identified in the melt inclusions: calcite, dolomite, magnesite, $\mathrm{Ca}-\mathrm{Ba}$ carbonate, phlogopite - tetraferriphlogopite, Na-K chlorides, Cr-Ti-Fe spinel, apatite, pyrochlore $(\mathrm{Na}, \mathrm{Ca})_{2} \mathrm{Nb}_{2} \mathrm{O}_{6}(\mathrm{OH}, \mathrm{F})$, K-bearing nahpoite $\mathrm{Na}_{2}\left(\mathrm{HPO}_{4}\right)$, djerfisherite $\mathrm{K}_{6} \mathrm{Na}(\mathrm{Fe}, \mathrm{Ni}, \mathrm{Cu})_{24} \mathrm{~S}_{26} \mathrm{Cl}$, and possibly 
gregoryite $\left(\mathrm{Na}_{2}, \mathrm{~K}_{2}, \mathrm{Ca}\right) \mathrm{CO}_{3}$, nyerereite $\mathrm{Na}_{2} \mathrm{Ca}\left(\mathrm{CO}_{3}\right)_{2}$, burbankite $(\mathrm{Na}, \mathrm{Ca})_{3}(\mathrm{Sr}, \mathrm{REE}, \mathrm{Ba})_{3}(\mathrm{CO} 3)_{5}, \quad$ shortite $\mathrm{Na}_{2} \mathrm{Ca}_{2}\left(\mathrm{CO}_{3}\right)_{3}$ and/or zemkorite $(\mathrm{Na}, \mathrm{K})_{2} \mathrm{Ca}\left(\mathrm{CO}_{3}\right)_{2}$, and northupite $\mathrm{Na}_{3} \mathrm{Mg}\left(\mathrm{CO}_{3}\right)_{2} \mathrm{Cl}$ and bradleyite $\mathrm{Na}_{3} \mathrm{Mg}\left(\mathrm{CO}_{3}\right)\left(\mathrm{PO}_{4}\right)$.

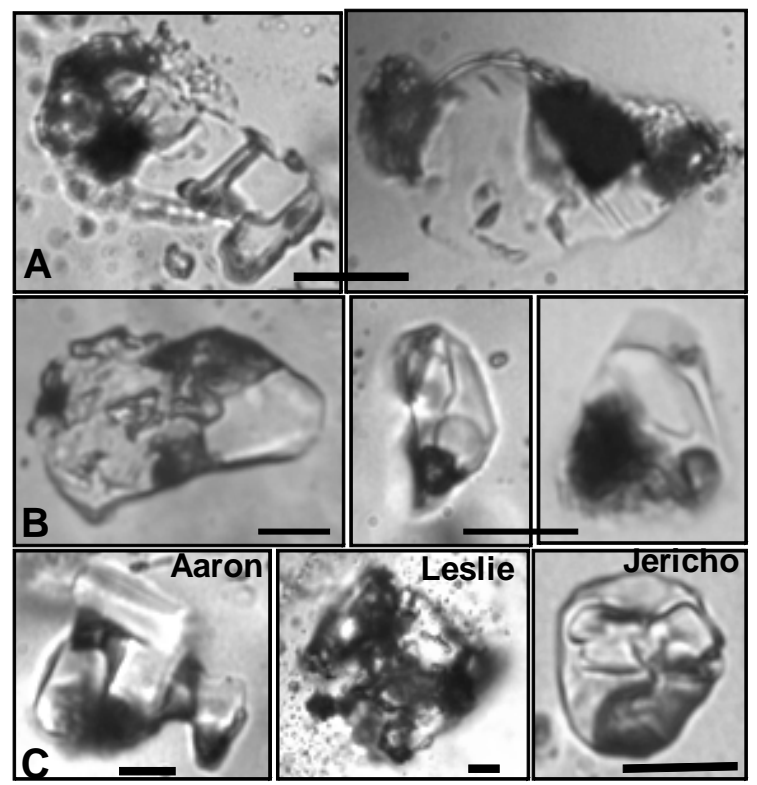

Fig. 1. Inclusions in olivine phenocrysts: A - Majuagaa calcite-kimberlite dyke, West Greenland; B -Gahcho Kué, Canada; C -Aaron, Leslie and Jericho pipes, Canada. Scale bar - $10 \mu \mathrm{m}$

Melt inclusions are significantly more enriched in the alkali elements relative to Ca than their host rocks. The Majuagaa kimberlite melt inclusions have $\left(\mathrm{Na}_{2} \mathrm{O}+\mathrm{K}_{2} \mathrm{O}\right) / \mathrm{CaO}=0.21-0.52$ (cf $0.03 \pm 0.02$ in the whole rocks), and $\mathrm{Na}$ dominates over $\mathrm{K}$. The averaged ratios of signal intensities of total alkalies $\left({ }^{23} \mathrm{Na}\right.$ and ${ }^{39} \mathrm{~K}$ ) versus ${ }^{35} \mathrm{Cl}$ are similar in the Majuagaa and Udachnaya-East melt inclusions. The lithophile trace element compositions of the melt inclusions, normalized to $\mathrm{Zr}$ content in the average whole rock kimberlites, are remarkably similar to the host kimberlite, but lack depletion in $\mathrm{Ba}$ and $\mathrm{Pb}$. Negative anomalies of $\mathrm{K}$ and $\mathrm{Rb}$ are present, but are much less pronounced (Fig. 2).

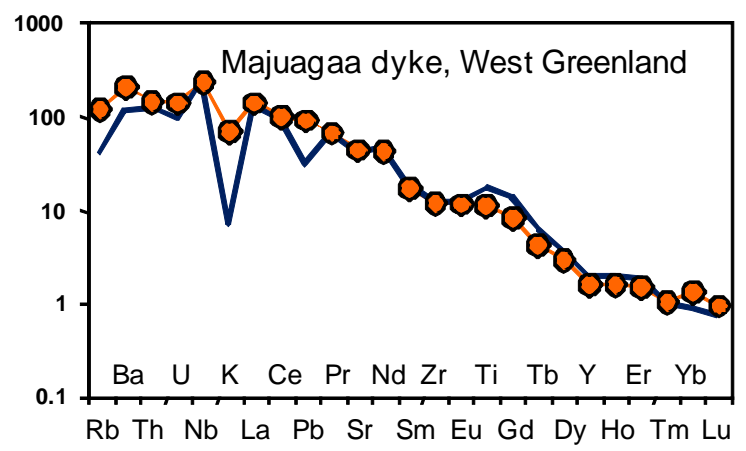

Fig. 2. "Primitive-mantle" normalized compositions of average melt inclusions (circles) and whole rock (solid line) of the Majuagaa kimberlite dyke, W. Greenland

Thermometric experiments with olivine-hosted multiphase melt inclusions from the Jericho and
Gahcho Kue' pipes and Greenland kimberlites showed beginning of melting at $\sim 550^{\circ} \mathrm{C}$. Homogenisation by bubble dissolution and complete melting and/or liquid mixing happens at $650-800^{\circ} \mathrm{C}$ (Fig. 3). It is most likely that during heating the solid phases become droplets of different liquids that continuously change shape and position relative to each other, coalesce and diminish in size. On cooling immiscibility and crystallisation of melt inclusions occurs down to very low temperatures $\left(570-380^{\circ} \mathrm{C}\right)$. The low temperatures of homogenisation and phase transformations suggest essentially nonsilicate compositions of melt inclusions, as also recorded in melt inclusions from the Udachnaya-East kimberlite (Kamenetsky et al., 2004; Kamenetsky et al., 2007).

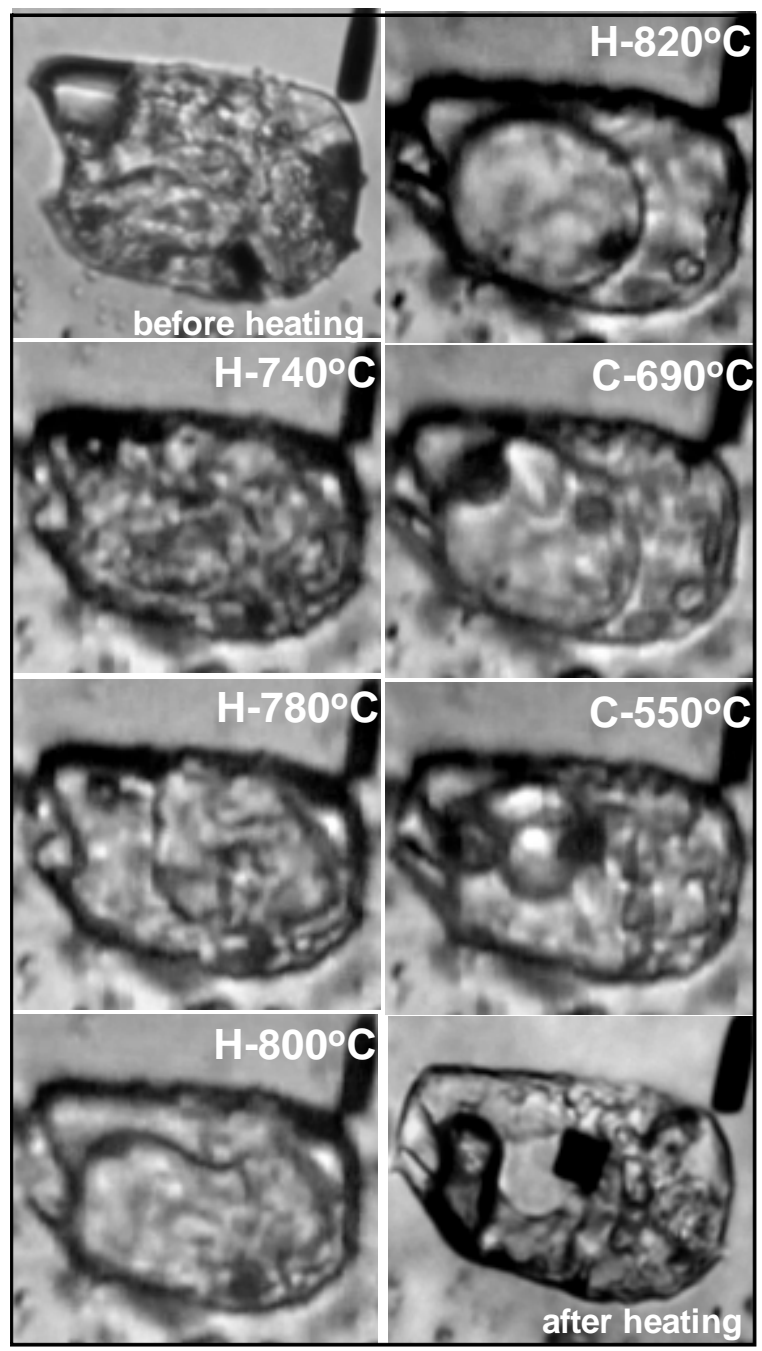

Fig. 3. Heating $(\mathrm{H})$ and cooling $(\mathrm{C})$ experiment with an olivine-hosted melt inclusion from the Gahcho Kué kimberlite, Canada

\section{Chlorine in serpentine}

Serpentine minerals, replacing single olivine crystals belong to several generations. The highest $\mathrm{Cl}$ content is in the early serpentine, which occurs around olivine relics (Fig. 4). Randomly analysed serpentine replacing olivine has $\mathrm{Cl}$ contents of $0.14-2.56 \mathrm{wt} \%$ (average $0.84 \pm 0.43 \mathrm{wt} \%, \mathrm{n}=70$ ) in the Jericho kimberlite and 
$0.10-1.76$ wt $\%$ (average $0.53 \pm 0.26$ wt $\%, n=88$ ) in the Gahcho Kué kimberlite.

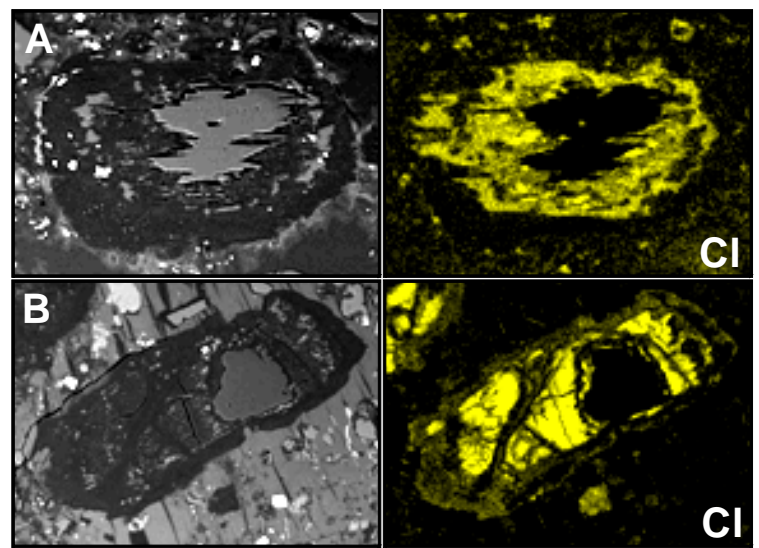

Fig. 4. Backscattered electron images and X-ray $\mathrm{Cl}$ maps showing distribution of $\mathrm{Cl}$ in alteration products (serpentine) of olivine phenocrysts from Slave Craton kimberlites: A - Jericho pipe; B- Gahcho Kué pipe.

\section{Discussion}

This study of kimberlites, emplaced in nonsedimentary crustal terrains, provides additional constraints on the chemical signature of kimberliteforming melts that was obscured or obliterated by postmagmatic alteration. Daughter phase mineralogy and bulk chemical composition of olivine-hosted melt inclusions and their behaviour during heating and cooling reveal close similarity between the parental melts of the studied kimberlites and that of the Udachnaya-East. The compositions of the melt inclusions are indeed representative of the parental melt, as they perfectly match the kimberlite groundmass for most lithophile trace elements, except elements that are prone to leaching during rock alteration. The compositions of melt inclusions have low abundances of the aluminosilicate component, but are enriched in alkali-bearing carbonates, chlorides and phosphates, that are responsible for low melting temperatures. High abundances and heterogeneous distribution of chlorine in the serpentine replacing kimberlitic olivine is important in understanding the composition of late-stage deuteric fluids derived from kimberlite rocks. The $\mathrm{Cl}$ content of metasomatic fluids was at its peak at the beginning of replacement, gradually decreased with further influx of meteoric waters, and completely removed upon the completion of serpentinisation.

Our study of partially altered kimberlites from Canada and Greenland, aimed at comparison with the fresh Udachnaya-East kimberlite and followed by implications of sodium- and chlorine-rich compositions of the parental kimberlite melt, has a precedent in the history of petrological and mineralogical studies of carbonatites. While all ancient intrusive and extrusive carbonatite rocks are composed of calcite and/or dolomite, the presently erupting carbonatitic magmas of the Oldoinyo Lengai volcano in Tanzania provides evidence carbonatite formation from alkali- and halogen-rich anhydrous melts. A strong support for the role of alkalies and halogens in magmas parental to mafic silicate intrusions and related carbonatites is further provided by numerous studies of daughter phases in melt/fluid inclusions and "fenitisation halos" (mainly soda-dominant) around intrusive bodies. Rapid decomposition of alkali- and chlorine-bearing minerals, as seen in the natrocarbonatites, can be similarly important in shaping compositions of kimberlites.

The groundmass of most kimberlites, including those studied here and altered kimberlites from the Udachnaya pipe, contain no alkali carbonates and chlorides and have very little $\mathrm{Na}_{2} \mathrm{O}(<0.2$ wt\%). We believe that alteration disturbs original melt compositions, with the alkaline elements and chlorine being mostly affected. However, the compositions of melt inclusions and serpentine are indicative of the chemical signature of a melt in which olivine crystallised and accumulated. It appears that enrichment in alkalies and chlorine, as seen in unaltered Udachnaya-East kimberlites, has been significant in other kimberlites prior to their alteration, and thus can be assigned to deep mantle origin.

We are grateful to Dante Canil Maya Kopylova and Casey Hetman for donating samples for this study.

\section{References}

Fedortchouk, Y. and Canil, D., 2004. Intensive variables in kimberlite magmas, Lac de Gras, Canada and implications for diamond survival. Journal of Petrology, 45: 1725-1745.

Hetman, C.M. et al., 2004. Geology of the Gahcho Kue kimberlite pipes, NWT, Canada: root to diatreme magmatic transition zones. Lithos, 76: 51-74.

Kamenetsky, M.B. et al., 2004. Kimberlite melts rich in alkali chlorides and carbonates: a potent metasomatic agent in the mantle. Geology, 32: 845848.

Kamenetsky, V.S et al., 2007. Chloride and carbonate immiscible liquids at the closure of the kimberlite magma evolution (Udachnaya-East kimberlite, Siberia). Chemical Geology, 237: 384-400.

Kamenetsky, V.S. et al., 2008. Olivine in the Udachnaya-East kimberlite (Yakutia, Russia): types, compositions and origins. Journal of Petrology, 49: 823-839.

Nielsen, T.F.D. and Jensen, S.M., 2005. The Majuagaa calcite-kimberlite dyke, Maniitsoq, southern West Greenland, Geological Survey of Denmark and Greenland, Report 2005/43.

Price, S.E. et al., 2000. Primitive magma from the Jericho Pipe, NWT, Canada: Constraints on primary kimberlite melt chemistry. Journal of Petrology, 41: 789-808. 